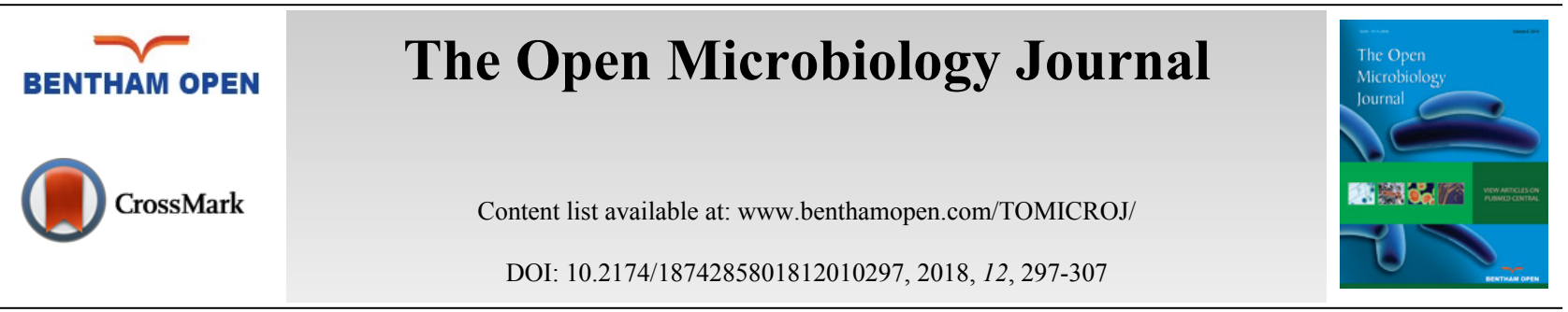

RESEARCH ARTICLE

\title{
Cadmium Removal from Aqueous Solutions by Strain of Pantoea agglomerans UCP1320 Isolated from Laundry Effluent
}

Leonila. M. L. Acioly ${ }^{1,5}$, Davi Cavalcanti ${ }^{1,5}$, Marcos C. Luna ${ }^{2,5}$, José C. V. Júnior ${ }^{3,5}$, Rosileide F. S. Andrade $^{4,5}$, Thayse A. de Lima e Silva ${ }^{4,5}$, Camilo E. La Rotta ${ }^{5}$ and Galba M. Campos-Takaki ${ }^{5, *}$

${ }^{I}$ Post Graduate Program in Biological Sciences, Federal University of Pernambuco, 50670-420, Recife, PE, Brazil

${ }^{2}$ Northeast Network for Biotechnology-RENORBIO, Federal Rural University of Pernambuco, 52171-900 Recife-PE, Brazil

${ }^{3}$ Autarchy of Higher Education of Garanhuns (AESGA), 55295-380 Garanhuns, Pernambuco, Brazil

${ }^{4}$ National Post-Doctorate Program (PNPD)-CAPES, Catholic University of Pernambuco, 50050-900, Recife, Pernambuco, Brazil

${ }^{5}$ Nucleus of Research in Environmental Sciences and Biotechnology, Catholic University of Pernambuco, 50050-590, Recife, PE, Brazil

\section{Abstract:}

\section{Background:}

Cadmium $(\mathrm{Cd})$, which is a deadly heavy metal of work-related and environmental concern, has been recognized as a substance that is teratogenic and carcinogenic for humans. Therefore, the need to develop low-cost adsorbents to remove heavy metals from aqueous solution has greatly increased. Adsorbents such as Pantoea agglomerans biomass have been used.

Aims:

We investigated the biotechnological potential of Pantoea agglomerans for the biosorption of cadmium from aqueous solution.

\section{Patients and Methods:}

Pantoea agglomerans UCP1320 isolated from the effluent of a laundry industry was used to remove cadmium from aqueous solutions. Two approaches were compared using active or thermally inactivated biomass. Three different cadmium concentrations of 1,10 and $100 \mathrm{ppm}$ were used under constant stirring at temperatures of $25^{\circ} \mathrm{C}$ and $35^{\circ} \mathrm{C}$ as was pH of $3.0,5.0$ and 7.0 . Variable incubation times of 1,6 , and $24 \mathrm{~h}$ were also studied.

\section{Results:}

The results showed that the temperature did not influence the uptake of metal by living cells nor by inactive bacterial biomass. However, increasing the $\mathrm{pH}$ had a positive effect on removing intermediate concentrations of cadmium. Low concentrations of cadmium were completely removed by both live and inactive biomass.

\section{Conclusion:}

Pantoea agglomerans biomass was shown to have a promising performance for the biotechnological removal of cadmium which had been dissolved in aqueous solution.

Keywords: Pantoea agglomerans, Pollution, Heavy metal, Biosorption, Absorption isotherms, Pollutants.

\footnotetext{
* Address correspondence to this author at the Nucleus of Research in Environmental Sciences and Biotechnology, Catholic University of Pernambuco, 50050-590, Recife, PE, Brazil; Tel: + 55812119 4017; E-mail: galba_takaki@yahoo.com.br
} 


\section{INTRODUCTION}

The constant discharge of different pollutants such as organic compounds and heavy metals into the environment is causing growing concern throughout the entire world. Several human activities have driven the increase in heavy metals being discharged into the environment. The question now is how to combat the rise in concentrations since these jeopardize human and animal health. In parallel, scientific advances have dealt with how to exploit natural resources without provoking the detrimental effects caused by many pollutants that have provoked environmental problems over many years [ 1 - 3]. In this context, the use of bioremediation as a tool offers the possibility of removing or transforming these long-studied pollutants into harmless compounds, based on the natural activity of various microorganisms. In addition, bioremediation has been gaining public attention and acceptance when it can be shown that this can be done at low cost, is effective, and it is feasible to apply it in locus. Compared to other non-biological technologies, bioremediation is one of the most promising and least costly alternatives for removing pollutants from soil, air and water $[4-6]$.

The presence of heavy metals such as cadmium, chromium, lead, zinc, copper and mercury are a constant threat to the environment since these metals tend to accumulate, thereby adversely affecting several biological niches [7,8].

Cadmium is a heavy metal that is difficult to degrade. It is known for its high binding capacity to biomolecules and especially to the enzymes present in the respiratory chain, thus leading to oxidative stress and physiological problems, including cancer $[8,9]$. Most cadmium is obtained as a by-product when smelting zinc, lead, or copper ores.

Metal (Cadmium) by-products are mostly used in metal plating and to make pigments, batteries, and plastics. This metal can be discharged into the soil in the form of urban, industrial sludge and in wastewaters. In addition, it can also be easily absorbed by and translocated in plants which are how it enters the food chain of humans and cattle. The results of some animal studies show that animals given cadmium-contaminated food and water develop high blood pressure, iron-poor blood, liver disease, nerve damage or brain damage [10, 11].

Conventional methods of removing metals such as precipitation, oxidation or reduction have been commonly used to remove heavy metal from industrial wastewater. They are ineffective or expensive, however. Substitute methods of metal removal and revival based on biological resources have been considered. Certain types of microbial biomass can retain comparatively high quantities of metal by means of passive processes known as biosorption [12, 13]. Such processes are of industrial interest, since the removal of potentially hazardous concentrations of cadmium can be achieved $[14,15]$.

Microorganisms use mainly two different processes for transforming and immobilizing heavy metals. One is called bioaccumulation, which is based on incorporating the metal pollutant into the living biomass. In the other main process, called biosorption, metallic ions remain on the cellular surface by different mechanisms [16]. Both methods show variable advantages related to operational costs, the volume of the residue to be treated and the biological waste to be disposed of, the efficiency of detoxification and removal, nutritional requirements and dilutions. However, the biological removal process is quite efficient, fast and is performed under mild operational conditions [17].

In the aquaculture industry is currently controlled with copper as a biocide paints problem. The development of these activities has resulted in marine and freshwater sediments next to the culture centers high levels of copper. In this sense, Pantoea agglomerans showed a high resistance for copper, as well as ability to remove copper. The aquaculture industry paints floating cages to prevent microorganisms adhering to them but this leads to high levels of copper in the paint being in contact with marine and freshwater sediments. Pantoea agglomerans has been used as it has a high resistance to copper and is able to remove copper from these sediments. The authors suggest that marine bacteria could be used in a biological system to remove copper [18]. This article describes the characterization of the biotechnological potential of the strain of Pantoea agglomerans on cadmium in aqueous solutions when biosorption and bioaccumulation bioprocesses are used.

\section{MATERIAL AND METHODS}

\subsection{Microorganism, Culture Media and Conditions}

Pantoea agglomerans is a Gram-negative bacterium that belongs to the family Enterobacteriaceae. The bacterium was isolated from laundry effluent and was identified as Pantoea agglomerans (UCP 1320) according to Acioly et al. [19] and deposited in the Culture Collection UCP (Universidade Católica de Pernambuco), Recife-PE, Brazil, and was 
registered in the WFCC (World Federation for Culture Collection).

The biomass from P. agglomerans was obtained following the methodology described by Hernandez et al. [20]. The bacterium was cultivated overnight in metal-free Luria-Bertani solid medium agar [21] at $30^{\circ} \mathrm{C}$. Then colonies were harvested and suspended in normal saline solution, centrifuged at $10.000 \mathrm{~g}$ for $20 \mathrm{~min}$ at $10^{\circ} \mathrm{C}$, and washed twice with the same solution and finally lyophilized. To obtain the inactivated biomass, the cell suspensions were submitted to autoclaving at $121^{\circ} \mathrm{C}$ for $15 \mathrm{~min}$ [22]. After cooling, cells were lyophilized and kept in a desiccator until constant weight.

\subsection{Experiments of Biosorption and Bioaccumulation}

These experiments were performed using $100 \mathrm{mg}$ of active or inactivated biomass per each $250 \mathrm{~mL}$ flask filled with $100 \mathrm{~mL}$ cadmium chloride solutions of $1.0,10.0$ and $100.0 \mathrm{ppm}$ of $\left(\mathrm{Cd}^{2+}\right)$ in normal saline solution. The effect of $\mathrm{pH}$ was evaluated by adjusting the $\mathrm{pH}$ with $\mathrm{HCl}$ or $\mathrm{NaOH}\left(1 \mathrm{~mol} . \mathrm{L}^{-1}\right)$ to final values of 3.0, 5.0 and 7.0. Finally, the effect of different temperatures was evaluated at 25 and $35^{\circ} \mathrm{C}$. All assays were incubated for $24 \mathrm{~h}$ under continuous stirring at $150 \mathrm{rpm}$. Samples of $(5 \mathrm{~mL})$ at $\mathrm{T}, \mathrm{T}_{1}, \mathrm{~T}_{6}$ and $\mathrm{T}_{24} \mathrm{~h}$ were taken. All assays were performed in duplicate and also two samples were taken each time.

\subsection{Electrochemical Method for Quantifying Cadmium}

Each sample was centrifuged at $9.000 \mathrm{rpm}$ for $20 \mathrm{~min}$, and the cell free supernatants were used to quantify cadmium. Residual Cd (II) was analyzed by Anodic Stripping Voltammetry (ASV) and Square wave Voltammetry (SWV). Stripping analysis is an analytical technique that involves the pre-concentration of a metal phase [23 - 25]. A glassy carbon electrode $(0.5 \mathrm{~cm}$ in diameter) was used as a working electrode; a Platinum wire as a counter electrode and an electrode of $\mathrm{AgCl}$ in saturated $\mathrm{KCl}$ was used as a reference electrode. As support electrolytes, $100 \mathrm{mmol} \mathrm{L}^{-1}$ solutions of $\mathrm{H}_{3} \mathrm{PO}_{4}$ or $\mathrm{KCl}$ were used. Quantification was performed from calibration curves of variable concentrations of $\mathrm{Cd}(\mathrm{II})$ as $\mathrm{CdCl}_{2}$ in $20 \mathrm{mmol} \mathrm{L}^{-1} \mathrm{HCl}$ ranging from 1.0 to $20 \mathrm{ppm}$. Electrochemical parameters for ASV include: $\mathrm{E}_{\mathrm{c}}=$ $0.6 \mathrm{~V}, \mathrm{~T}_{\mathrm{c}}=60 \mathrm{~s}, \mathrm{E}_{\mathrm{d}}=-1.4 \mathrm{~V}$ and $\mathrm{t}_{\mathrm{d}}=60 \mathrm{~s}$. And for SWV of: $\mathrm{F}=25 \mathrm{~Hz} ; \mathrm{E}=-1.4 \mathrm{~V}, \mathrm{E}_{\mathrm{f}}=0,0, \mathrm{E}_{\text {step }}=0.005$ and wave width $=0.025 \mathrm{mV}$.

\subsection{Determining Removal and Calculating Absorption Isotherms}

Removal percentages were determined as per Equation 1:

$$
\text { Removal, } \%=\left(C_{o}-C_{f} / C_{o}\right) * 100
$$

where $\mathrm{C}_{\mathrm{o}}$ corresponds to the initial concentration of $\mathrm{Cd}(\mathrm{II})$ and $\mathrm{C}_{\mathrm{f}}$, the final concentration after the sorption processes caused by the chitosan membrane. The metal uptake capacity, $q$, for a $\mathrm{Cd}(\mathrm{II})$ ion was calculated as:

$$
q_{t}=V / m\left(C_{0}-C_{f}\right)
$$

where $q_{t}, C, C_{f}, V$ and $m$ are the amount of solute adsorbed per unit weight of adsorbent $\left(\mathrm{mg} \mathrm{g}^{-1}\right)$ at $\mathrm{t}(\mathrm{min})$, the initial metal ion concentration, the final metal ion concentration $\left(\mathrm{mg} \mathrm{L}^{-1}\right)$, the volume $(\mathrm{L})$ of the solution and the dry weight of adsorbent $(\mathrm{g})$, respectively. The amount of cadmium adsorbed by adsorbents, $q$, was determined by:

$$
q_{e}=V / m\left(C_{0}-C_{e}\right)
$$

In this Equation, $q_{e}$ and $C_{e}$ are the amount of solute adsorbed per unit weight of adsorbent $(\mathrm{mg} / \mathrm{g})$ at equilibrium and the equilibrium concentration of cadmium $(\mathrm{mg} / \mathrm{L})$, respectively. The three most widely used adsorption isotherms are the Langmuir, Freundlich and Dubinin-Radushkevich (D-R) isotherms. In this study, experimental data were analyzed in terms of the Langmuir adsorption isotherm equation in linear form which is:

$$
1 / q_{e}=\left(1 / q_{\max } \cdot K_{L}\right) \cdot 1 / C_{e}+1 / q_{\max }
$$

where $q_{\max }$ is the maximum adsorption capacity of adsorbent $(\mathrm{mg} / \mathrm{g})$ and $K_{L}$ is the Langmuir constant related to the energy of adsorption $\left(\mathrm{L} \mathrm{mg}^{-1}\right) . K_{L}$ and $q_{\max }$ can be calculated from the slope and intercept of the linear plot of $1 / q_{e} v e r s u s$ $1 / C_{e}$. 


\section{RESULTS}

\subsection{Effect of pH, Temperature and Incubation Time Over Cadmium Biosorption By Biomass of P. agglomerans}

As a control experiment, we used thermal inactivated cells of P. agglomerans in an attempt to determine if the removal was caused by the biomass itself (sorption processes) or by any other metabolic process involved (bioremediation processes). When the inactivated cells were put in contact with low concentrations of cadmium, very high to almost complete removal was achieved, with some interesting exceptions.

Fig. (1) shows the results in terms of the Cd (II) removal achieved with the inactivated cells of P. agglomerans, when incubated at temperatures of $25^{\circ} \mathrm{C}(\mathrm{A})$ or $35^{\circ} \mathrm{C}(\mathrm{B})$, respectively. As can be seen, noticeable increases were observed at $25^{\circ} \mathrm{C}$, when the biomasses were incubated at higher $\mathrm{pH}$ values. This observation was even more evident when $\mathrm{pH}$ changed from 3.0 to 5.0, while between 5.0 and 7.0 the increase was almost insignificant.
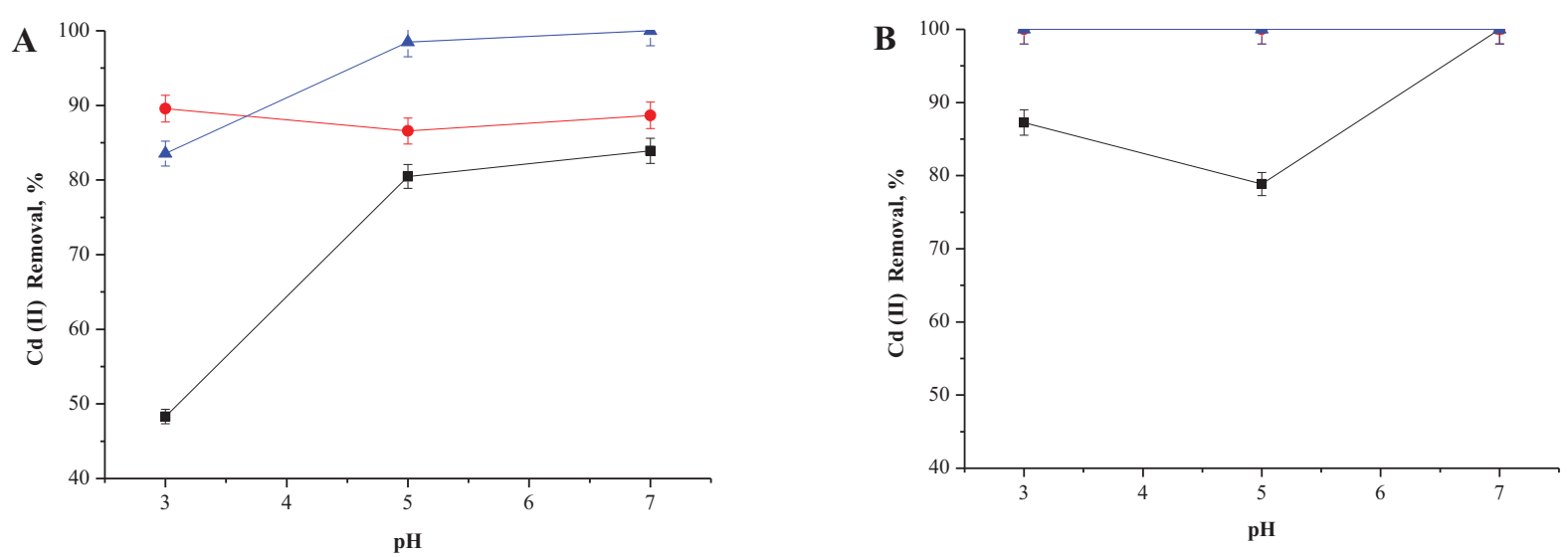

Fig. (1). Cadmium adsorption (10 ppm) by inactivated cells of $P$. agglomerans at temperature of $25^{\circ} \mathrm{C}(\mathrm{A})$ and $35^{\circ} \mathrm{C}(\mathrm{B})$, respectively on $\mathrm{pH} 3$ to 7 . Incubation times of $1 \mathrm{~h}$ (square), $6 \mathrm{~h}$ (circle) and $24 \mathrm{~h}$ (triangle).

On the other hand, when the incubation period was extended up to $24 \mathrm{~h}$, the highest removal of Cd (II) was achieved in $\mathrm{pH}$ values between 5.0 and 7.0. This amounted to the removal of $100 \%$ at $24 \mathrm{~h}$. Conversely, at a higher temperature of $35^{\circ} \mathrm{C}$ maximum removals of $100 \%$ were achieved after $6 \mathrm{~h}$ of incubation.

The Fig. (2) shows the effect of the $\mathrm{pH}$ on cadmium removals obtained using living cells of P. agglomerans, incubated at 25 or $35^{\circ} \mathrm{C}$ in aqueous solutions containing $10 \mathrm{ppm}$ of $\mathrm{Cd}(\mathrm{II})$.
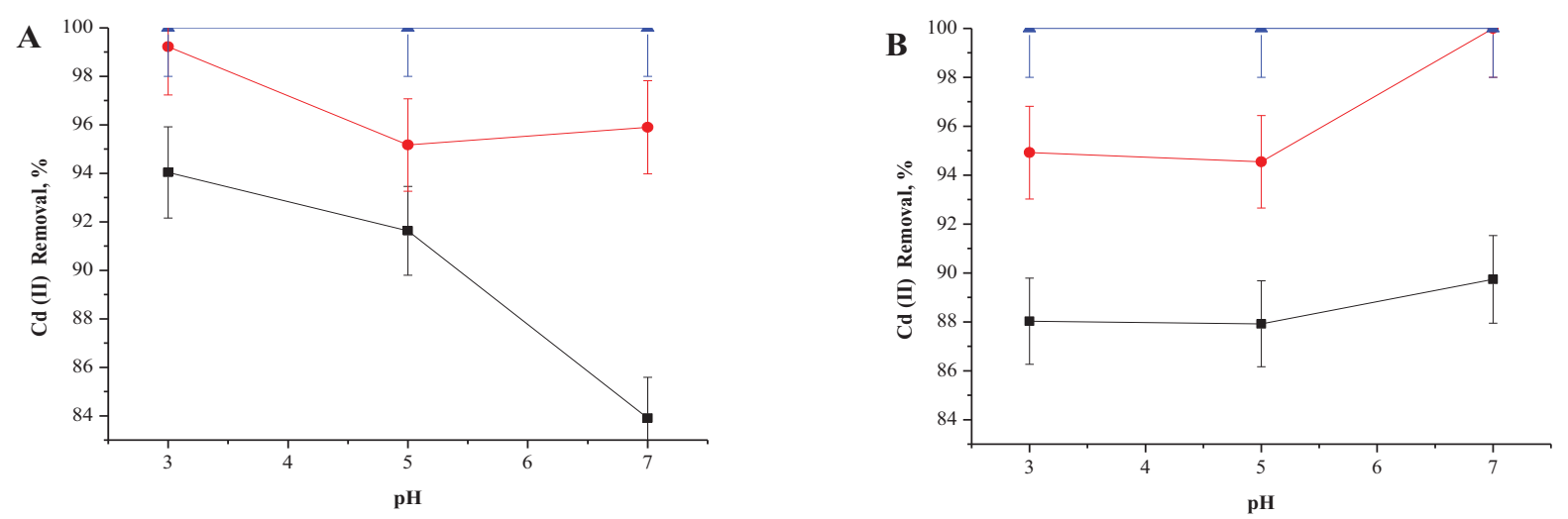

Fig. (2). Cadmium adsorption (10 ppm) by living cells of $P$. agglomerans at $25^{\circ} \mathrm{C}(\mathrm{A})$ and $35^{\circ} \mathrm{C}(\mathrm{B})$, respectively on $\mathrm{pH} 3$ to 7. Incubation times of $1 \mathrm{~h}$ (square), $6 \mathrm{~h}$ (circle) and $24 \mathrm{~h}$ (triangle).

As can be observed, higher removal was achieved at lower temperatures and lower $\mathrm{pH}$ values. As such, the best 
overall results were obtained when $P$. agglomerans cells were incubated at $\mathrm{pH} 3.0$ and $25^{\circ} \mathrm{C}$. Interestingly, at the same incubation temperature, but with a $\mathrm{pH}$ of 7.0 , a decrease of almost $20 \%$ in $\mathrm{Cd}$ (II) removal was observed, while at $35^{\circ} \mathrm{C}$ slight increases were observed at the same $\mathrm{pH}$ value. As we expected, the best results were achieved in all cases at higher incubation times. Thus, $100 \%$ of Cd (II) was removed from the aqueous solutions by the living cells after $24 \mathrm{~h}$, no matter the $\mathrm{pH}$ value or incubation temperature.

Table 1 summarizes the results obtained for the maximum removals achieved using 10 ppm of Cd (II) and both active and inactivated cells of $P$. agglomerans. When living cells of $P$. agglomerans were used both removal processes are expected to occur simultaneously, one related to the cell metabolism and the other to physical interactions between the heavy metals and the biological structures existing in the cells.

Table 1. Comparison between Cd(II) maximum removals (10ppm) due to the biosorption or biotransformation using inactivated biomass and living cells of $P$. agglomerans incubated for 6 h.

\begin{tabular}{|c|c|c|c|c|c|c|}
\hline pH/Temperature & \multicolumn{2}{|c|}{ Both Sorption and Metabolic Removal (\%) } & \multicolumn{2}{|c|}{$\begin{array}{c}\text { Only Sorption } \\
\text { Removal (\%) }\end{array}$} & \multicolumn{2}{c|}{ Real Removal (\%) Due to Bacterial Metabolism } \\
\hline & $\mathbf{2 5}{ }^{\circ} \mathbf{C}$ & $\mathbf{3 5}{ }^{\circ} \mathbf{C}$ & $\mathbf{2 5}^{\circ} \mathbf{C}$ & $\mathbf{3 5}{ }^{\circ} \mathbf{C}$ & $\mathbf{2 5}^{\circ} \mathbf{C}$ & $\mathbf{3 5}^{\circ} \mathbf{C}$ \\
\hline $\mathrm{pH} \mathrm{3.0}$ & 99.22 & 94.92 & 89.56 & 87.26 & 9.66 & 7.66 \\
\hline $\mathrm{pH} .5 .0$ & 95.17 & 94.55 & 86.57 & 78.85 & 8.60 & 15.70 \\
\hline $\mathrm{pH} 6.0$ & 95.90 & 100.0 & 88.66 & 100.0 & 7.24 & 0 \\
\hline
\end{tabular}

The global removal was slightly higher than the one observed for the sorption process due only to physic-chemical interactions, especially when the processes were performed at the higher temperature of $35^{\circ} \mathrm{C}$. The best overall results were obtained at $\mathrm{pH} 6.0$ and $35^{\circ} \mathrm{C}$. Since these conditions are closely related to the physiological conditions where the bacterium grows, the increase in the removal can be expected to be related to the biological activity. When the maximum removals observed by the inactivated cells were subtracted from those obtained for the living cells, real removal values were obtained corresponding only to the cellular metabolism. Therefore, a maximum removal of $15 \%$ was observed for bacterial metabolism at $\mathrm{pH} 5.0$ and $35^{\circ} \mathrm{C}$. Since the values for removal observed for all $\mathrm{pH}$ values tested at $25^{\circ} \mathrm{C}$ were close to each other, this clearly indicates that the removal was mostly driven by the increase in the temperature rather than being due to $\mathrm{pH}$ at low concentrations of $\mathrm{Cd}$ (II).

\subsection{Effect of Cd(II) Concentration Over Biosorption}

The effect of Cd (II) concentration was tested only up to $100 \mathrm{ppm}$ since higher concentrations of these heavy metals are rarely found above this limit in waste-waters.

As can be seen in Fig. (3), the increase of the Cd (II) removal occurs when the incubation time is extended, and the temperature and $\mathrm{pH}$ were increased. No significant variations were observed between $\mathrm{pH}$ values at 25 or $35^{\circ} \mathrm{C}$. However, $10 \%$ increases in variation were observed between $1 \mathrm{~h}$ and $6 \mathrm{~h}$ of incubation as was a $10 \%$ increase in removal when inactivated cells were incubated for up to $24 \mathrm{~h}$ at $25^{\circ} \mathrm{C}$. Lower increases in removal of a maximum of $10 \%$ were observed when cells were incubated at $35^{\circ} \mathrm{C}$ for up to $6 \mathrm{~h}$ and only $4 \%$ when incubated under the same conditions for up to $24 \mathrm{~h}$.
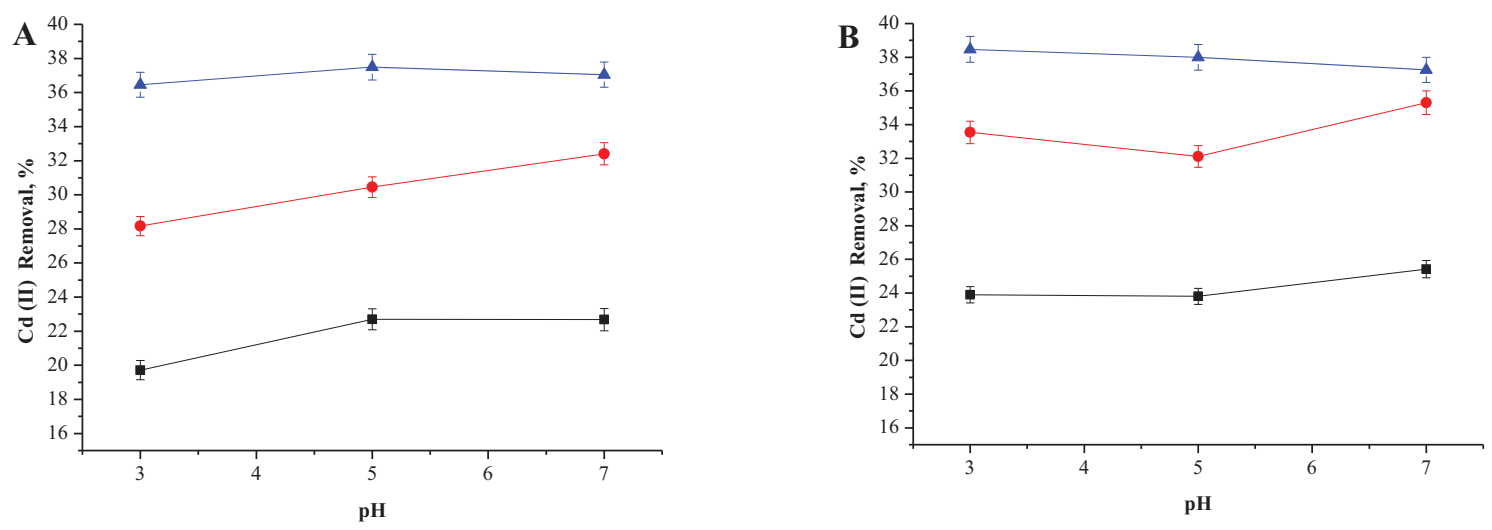

Fig. (3). Adsorption of Cadmium (100 ppm) by inactivated cells of P. agglomerans at $25^{\circ} \mathrm{C}(\mathrm{A})$ and $35^{\circ} \mathrm{C}(\mathrm{B})$, respectively on pH 3 to7. Incubation times of $1 \mathrm{~h}$ (square), $6 \mathrm{~h}$ (circle) and $24 \mathrm{~h}$ (triangle). 
In general, the best results were achieved at $\mathrm{pH} 7.0$ and $35^{\circ} \mathrm{C}$ after $24 \mathrm{~h}$. In contrast, Fig. (4) shows the results obtained for removing the same concentration of $\mathrm{Cd}$ (II) by active cells of $P$. agglomerans. As can be observed, when we increase the concentration of $\mathrm{Cd}$ (II) by one $\log$, removal decreases to one half of the value observed at lower concentrations of this metal. In both Fig. $(\mathbf{4 A}, \mathbf{B})$ it can be observed that the best results were achieved at the lower incubation time of $1 \mathrm{~h}$, and a slight increase in removal accompanied the increase in $\mathrm{pH}$ in all cases.
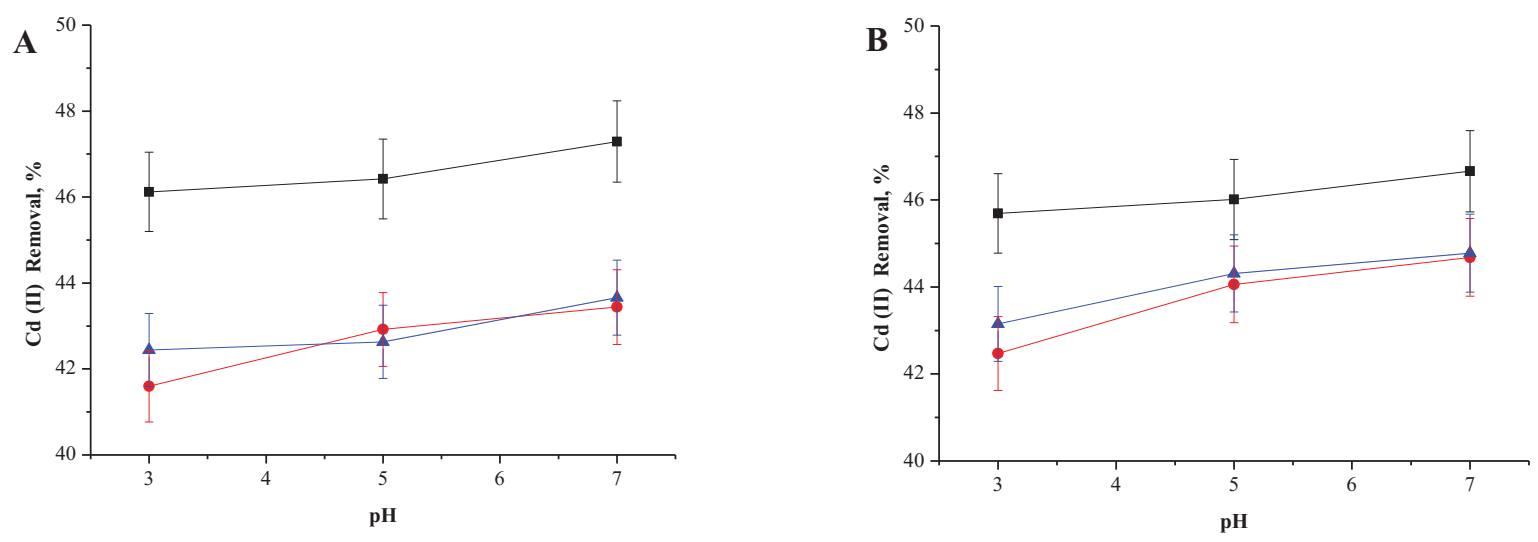

Fig. (4). Cadmium adsorption (100 ppm) by living cells of $P$. agglomerans at $25^{\circ} \mathrm{C}(\mathrm{A})$ and $35^{\circ} \mathrm{C}(\mathrm{B})$, respectively on pH 3 to 7. Incubation times of $1 \mathrm{~h}$ (square), $6 \mathrm{~h}$ (circle) and $24 \mathrm{~h}$ (triangle).

For higher concentrations of Cd (II) no relationship can be established between temperature changes since no significant variations were observed at 25 or $35^{\circ} \mathrm{C}$. However, what remains obvious is the fact that at longer incubation times, the probability of desorption can be expected between $6 \mathrm{~h}$ and $24 \mathrm{~h}$, since lower concentrations of Cd (II) were removed from the solutions. This can imply that the metal exerts toxicity on the cells, when they are able to remove up to $70 \mathrm{ppm}$ of cadmium, during the first hour, but then the metal caused cellular death and consequently for cellular lysis and this fosters releasing the metal releasing back to the solution.

\subsection{Effect of Cd(II) Concentration Over Biosorption}

The effect of Cd (II) concentration was tested only up to $100 \mathrm{ppm}$ since higher concentrations of these heavy metals are rarely found above this limit in waste-waters. As can be seen in Fig. (3), an increase in removing Cd (II) followed when the incubation period was extended, and also when both the temperature and $\mathrm{pH}$ were increased when inactivated cells were used as sorbent material. No significant variations were observed between $\mathrm{pH}$ values at $25^{\circ} \mathrm{C}$ or $35^{\circ} \mathrm{C}$. However, $10 \%$ increases in variation were observed between $1 \mathrm{~h}$ and $6 \mathrm{~h}$ of incubation as was a $10 \%$ increase in removal when inactivated cells were incubated for up to $24 \mathrm{~h}$ at $25^{\circ} \mathrm{C}$. Lower increases in removing a maximum $10 \%$ were observed when cells were incubated at $35^{\circ} \mathrm{C}$ for up to $6 \mathrm{~h}$ and the increase was only $4 \%$ when incubated under the same conditions for up to $24 \mathrm{~h}$.

In general, the best results were achieved at $\mathrm{pH} 7.0$ and $35^{\circ} \mathrm{C}$ after $24 \mathrm{~h}$. In contrast, Fig. (4) shows the results obtained for removing the same concentration of $\mathrm{Cd}$ (II) by active cells of P. agglomerans. As can be observed, when we increase the concentration of $\mathrm{Cd}$ (II) by one log, removal decreases to one half of the value observed at lower concentrations of this metal. In both Fig. (4A, B) it can be observed that the best results were achieved at the lower incubation time of $1 \mathrm{~h}$, and a slight increase in removal accompanied the increase in $\mathrm{pH}$ in all cases. For higher concentrations of $\mathrm{Cd}$ (II) no relationship can be established between temperature changes since no significant variations were observed at $25^{\circ} \mathrm{C}$ or $35^{\circ} \mathrm{C}$. However, what remains obvious is the fact that at longer incubation times, the probability of desorption can be expected between $6 \mathrm{~h}$ and $24 \mathrm{~h}$, since lower concentrations of Cd (II) were removed from the solutions. This can imply that the metal exerts toxicity on the cells, when they are able to remove up to 70 ppm of cadmium, during the first hour, but then the metal caused cellular death and consequently for cellular lysis and fosters releasing the metal releasing back to the solution.

Conversely, as to the observations made at low Cd (II) concentrations, the best results were achieved only at longer incubation times. Table 2 shows the summarized results obtained at these times for the incubation conditions used for both inactivated and active cells of $P$. agglomerans. As can be seen, no significant differences were observed between maximum Cd (II) removal values when both sorption and metabolic removals corresponding to the living cells were 
evaluated. However, lower results were obtained for the sorptive processes due only to the inactivated biomass. As such, the average value of removal caused only by the metabolism of the living cells was close to $6.00 \%$.

Table 2. Comparison between Cd(II) maximum removals (at $100 \mathrm{ppm}$ ), due to biosorption or biotransformation using inactivated biomass and living cells of $P$. agglomerans incubated for $24 \mathrm{~h}$.

\begin{tabular}{|c|c|c|c|c|c|c|}
\hline \multirow{2}{*}{ Temperature } & \multicolumn{2}{|c|}{ Both Sorptive and Metabolic Removal (\%) } & \multicolumn{2}{c|}{$\begin{array}{c}\text { Only Sorptive } \\
\text { Removal (\%) }\end{array}$} & \multicolumn{3}{|c|}{$\begin{array}{c}\text { Real Removal (\%) } \\
\text { Due to Bacterial Metabolism }\end{array}$} \\
\hline & $\mathbf{2 5}{ }^{\circ} \mathbf{C}$ & $\mathbf{3 5}^{\circ} \mathbf{C}$ & $\mathbf{2 5}^{\circ} \mathbf{C}$ & $\mathbf{3 5}{ }^{\circ} \mathbf{C}$ & $\mathbf{2 5}^{\circ} \mathbf{C}$ & $\mathbf{3 5}^{\circ} \mathbf{C}$ \\
\hline $\mathrm{pH} 3.0$ & 42.44 & 43.15 & 36.46 & 38.47 & 5.98 & 4.68 \\
\hline $\mathrm{pH} .5 .0$ & 42.63 & 44.31 & 37.49 & 37.99 & 5.14 & 6.32 \\
\hline $\mathrm{pH} 6.0$ & 43.66 & 44.78 & 37.05 & 37.25 & 6.61 & 7.35 \\
\hline
\end{tabular}

Table 3 shows the removal rates calculated for each experiment during $24 \mathrm{~h}$ of incubation. It was observed that the overall highest rates of 6.032 and $6.638 \mathrm{ppm} \mathrm{h}^{-1}$ were achieved at $\mathrm{pH} 7.0,35^{\circ} \mathrm{C}$ and $100 \mathrm{ppm}$ of Cd (II) for inactivated biomass and living cells, respectively. It must be noted that living cells of $P$. agglomerans also demonstrated good removal rates at $\mathrm{pH} 5.0$ and 3.0 from low $\mathrm{Cd}$ (II) concentrations of $10 \mathrm{ppm}$.

Table 3. Cd (II) Removal rates ( $\mathrm{ppm} \mathrm{h}^{-1}$ )observed for active and inactivated cells of $P$. agglomerans under the conditions studied.

\begin{tabular}{|c|c|c|c|c|c|c|c|c|}
\hline $\mathbf{p H}$ & TEMPERATURE & $\mathbf{C d}(\mathbf{I I})$ & \multicolumn{3}{|c|}{ INACTIVATED CELLS } & \multicolumn{3}{c|}{ LIVING CELLS } \\
\hline & ${ }^{\circ} \mathbf{C}$ & $\mathbf{p p m})$ & \multicolumn{3}{|c|}{$\left.\mathbf{( p p m ~ h}^{-1}\right)$} & \multicolumn{3}{c|}{$\left.\mathbf{( p p m ~ h}^{-1}\right)$} \\
\hline 3.0 & 25 & 10 & $\underline{1.667}$ & \pm & 0.033 & 5.231 & \pm & 0.104 \\
\hline 3.0 & 25 & 100 & 4.752 & \pm & 0.095 & 1.483 & \pm & 0.029 \\
\hline 3.0 & 35 & 10 & 1.609 & \pm & 0.032 & 5.989 & \pm & 0.119 \\
\hline 3.0 & 35 & 100 & 5.701 & \pm & 0.114 & 6.215 & \pm & 0.124 \\
\hline 5.0 & 25 & 10 & 1.340 & \pm & 0.026 & 1.463 & \pm & 0.029 \\
\hline 5.0 & 25 & 100 & 5.067 & \pm & 0.101 & 1.546 & \pm & 0.030 \\
\hline 5.0 & 35 & 10 & 1.352 & \pm & 0.027 & $\underline{6.276}$ & \pm & 0.125 \\
\hline 5.0 & 35 & 100 & 5.378 & \pm & 0.107 & 6.550 & \pm & 0.131 \\
\hline 7.0 & 25 & 10 & 1.525 & \pm & 0.030 & 1.535 & \pm & 0.030 \\
\hline 7.0 & 25 & 100 & 5.543 & \pm & 0.110 & 1.591 & \pm & 0.031 \\
\hline 7.0 & 35 & 10 & 1.519 & \pm & 0.030 & 6.324 & \pm & 0.126 \\
\hline 7.0 & 35 & 100 & $\underline{6.032}$ & \pm & 0.120 & $\underline{6.638}$ & \pm & 0.132 \\
\hline
\end{tabular}

In our study, the cadmium biosorption by Pantoea agglomerans showed a positive effect of removal using $\mathrm{pH}$ of between 5.0 - 6.0 and a temperature of $25^{\circ} \mathrm{C}$. The strain of P. agglomerans showed excellent removal capacity for $\mathrm{Cd}$ (II) at low concentrations of $1 \mathrm{ppm}$, in which both active and inactivated biomass were successful (data not shown).

\section{DISCUSSION}

The properties of cell wall constituents, such as peptidoglycan and the role of functional groups, such as carboxyl, amine and phosphonate are related to their biosorption potential [21]. The cell wall is the first component of the bacterial physiology that comes into contact with metallic ions, and this is where the solutes can be deposited either over its surface or inside it $[25,26]$. Since the absorption of solutes by inactive cells is mostly extracellular, the chemical moieties present on the cell wall perform a key role during biosorption. In addition, the increase in $\mathrm{pH}$ promotes the formation of negative-charged functional groups by deprotonation which favors the electrostatic attraction and adsorption of cations [27]. This fact was clearly demonstrated when both active and inactivated cells of $P$. agglomerans were incubated at variable $\mathrm{pH}$ values.

The efficiency of bioaccumulation by living cells depends on the conditions under which they grow, their physiological state and their age. For example, Mapolelo and Torto [28] mentioned that a pretreatment of S. cereviseae cells with glucose 10 to $20 \mathrm{mmolL}^{-1}$ enhanced removal of between 30 to $40 \%$ for $\mathrm{Cd}^{2+}, \mathrm{Cr}^{3+}, \mathrm{Cu}^{2+}, \mathrm{Pb}^{2+}$ and $\mathrm{Zn}^{2+}$. This observation was also reported by Stoll and Duncan [29] who studied the absorption of $\mathrm{Cu}^{2+}, \mathrm{Cd}^{2+}, \mathrm{Cr}^{6+}, \mathrm{Ni}^{2+}$ and $\mathrm{Zn}^{2+}$ by the same microorganism from galvanoplastic industrial effluents. The results were surprising since the pre-treatment of yeast cell with glucose was more efficient than directly adding glucose to the effluent. Perhaps, the growth achieved with $P$. agglomerans in LB culture medium supplemented with glucose $1 \%$ caused the active or inactivated cells of this 
bacterium to increase their capacity to remove $\mathrm{Cd}$ (II).

Abbas et al. (2014) described the high capacity of biosorption of heavy metal by biosorbent bacterium (Staphylococcus saprophyticus, Enterobacter cloacae, Pseudomonas sp., P. aeruginosa, Micrococcus sp., Thiobacillus thiooxidans, Bacillus sp., B. cereus, B. licheniformis, Geobacillus themodenitrificans, Actinomycete sp, and Micrococcus sp).

The data obtained from literature on the influence of $\mathrm{pH}$ on the biosorption of cadmium are inconsistent and some studies affirm that the $\mathrm{pH}$ could alter the adsorption of metallic ions by biomass, but other studies state that this also varies with the optimal $\mathrm{pH}$ values for the adsorbents (biomass), and the type of adsorbents [30 - 33].

Similar results of cadmium biosorption were obtained by Hou et al. [34] who reported cadmium biosorption by Klebsiella sp. at pH 5.0 and a temperature of $30^{\circ} \mathrm{C}$. In addition, it is important emphasize that the strain of Klebsiella sp. has approximately ten times the absorption capacity reported for other strains and is promising for the removal of heavy metals from waste water.

The optimal pH for Cd (II) adsorption for Saccharomyces cerevisiae is 6.5 [35] and for filamentous fungi is close to 8.0 [36]. Also, Ozdemir et al. [37] using inactivated biomass from Pantoea sp. proved the optimal pH for Cd(II) removal is at $\mathrm{pH}$ 6.0. Other studies using inactivated cells from different bacterial species such as Ochrobactrum anthropi showed optimal removal at pH 8.0 and for Pseudomonas aeruginosa PU21, pH 6.0 was also observed as the optimal condition $[38,39]$.

In our study, the effect of $\mathrm{pH}$ over the capacity of $\mathrm{Cd}$ (II) absorption shows that living cells as well as inactivated biomass are also able to remove this metal efficiently at low $\mathrm{pH}$ values of 3.0. But it was also confirmed that on increasing $\mathrm{pH}$ up to 7.0, the sorption availability was even better in the case of the inactivated cells. As mentioned before, the medium $\mathrm{pH}$ could also affect the solubility of some ions, and their ionization state will determine their capacity to bind to the carboxylate and phosphate groups present on the bacterial surface, these being powerful carriers of cations [37].

The remaining concentrations of $\mathrm{Cd}$ (II) were of $0.016 \mathrm{ppm}$ when Weissella viridescens and $0.089 \mathrm{ppm}$ for Lactobacillus sp were used [40]. Also, four species of L. mucosae and L. fermentum reduced the initial Cd (II) concentration to $0.074 \mathrm{ppm}$, while two strains of Streptococcus lactolyticus and two of Enterococcus faecalis showed residual concentrations of 0.651 and $0.633 \mathrm{ppm}$, respectively and strains of Pediococcus pentosaceus showed relatively low biosorption of $0.037 \mathrm{ppm}[40,41]$. These data justify once more the biotechnological potential use of Pantoea agglomerans as a biosorbent for environments polluted with heavy metals such as Cadmium (II).

Abbas et al. [15] described the high capacity of biosorption of heavy metal by biosorbent bacterium (Staphylococcus saprophyticus, Enterobacter cloacae, Pseudomonas sp., P. aeruginosa, Micrococcus sp., Thiobacillus thiooxidans, Bacillus sp., B. cereus, B. licheniformis, Geobacillus themodenitrificans, Actinomycete sp, and Micrococcus sp).

\section{CONCLUSION}

In the present study, the complete removal of Cadmium Cd (II) by Pantoea agglomerans from water by an electrochemical process has been investigated. According to the results from this study, we can affirm that the strain Pantoea agglomerans UCP1320 is an efficient biosorbent for Cd (II) in concentrations ranging from 1 to 100 ppm. Living cells or inactivated cells showed optimal removal conditions at $35^{\circ} \mathrm{C}$ and $\mathrm{pH}$ ranging 5.0 to 6.0 .

Electrochemical processing is an efficient technology for removing heavy metals from water and this methodology has been attracting increasing interest. This approach of using $P$. agglomerans to remove cadmium represents a promising, simple and cost-effective tool for treating and clearing this heavy metal pollutant from water.

\section{LIST OF ABBREVIATIONS}

$\begin{array}{lll}\text { ASV } & = & \text { Anodic Stripping Voltammetry } \\ { }^{\circ} \mathbf{C} & = & \text { Degree }(\mathrm{s}) \text { Celsius } \\ \mathbf{C d} & = & \text { Cadmium } \\ \text { ClAg } & = & \text { Silver chloride } \\ \mathbf{C r} & = & \text { Chromium }\end{array}$




$\begin{array}{lll}\mathbf{C u} & = & \text { Copper } \\ \mathbf{h} & = & \text { Hours } \\ \text { H3PO4 } & = & \text { Phosphoric acid } \\ \text { KCl } & = & \text { Potassium chloride } \\ \text { mg } & = & \text { Milligrams } \\ \text { min } & = & \text { Minute } \\ \text { Pb } & = & \text { Lead } \\ \text { pH } & = & \text { Potential hydrogen } \\ \text { SWV } & = & \text { Square Wave Voltammetry } \\ \text { Zn } & = & \text { Zinc }\end{array}$

\section{AUTHORS' CONTRIBUTIONS}

LMLA, CFLR and GMCT conceived and designed the experiments; LMLA, DC, MCL and JCVJ performed the experiments; LMLA, RFSA, TALS and CFLR analyzed the data; GMCT and CFLR contributed reagents/materials/analysis tools; LMLA, CFLR and GMCT wrote the paper.

\section{ETHICS APPROVAL AND CONSENT TO PARTICIPATE}

Not applicable.

\section{HUMAN AND ANIMAL RIGHTS}

No animals/humans were used for studies that are the basis of this research.

\section{CONSENT FOR PUBLICATION}

Not applicable.

\section{CONFLICT OF INTEREST}

The author declares no conflict of interest, financial or otherwise.

\section{ACKNOWLEDGEMENTS}

This work was financially supported by CNPq (National Council for Scientific and Technological Development) Process No. 311373/2014-3, FACEPE (Foundation for the Support of Science and Technology of the State of Pernambuco) Process No. APQ-0291-2.12/15, and the Coordination Unit for the Improvement of Higher Level Education Personnel (CAPES). The authors are especially grateful to the Bio-electrochemistry Laboratory of the NPCIAMB of the Catholic University of Pernambuco for making facilities and infrastructure available for the conduct of this research.

\section{REFERENCES}

[1] Chong MN, Jin B, Chow CWKC, Saint C. Recent developments in photocatalytic water treatment technology: A review. Water Res 2010; 44(10): 2997-3027.

[http://dx.doi.org/10.1016/j.watres.2010.02.039] [PMID: 20378145]

[2] Zeng GM, Li X, Huang JH, et al. Micellar-enhanced ultrafiltration of cadmium and methylene blue in synthetic wastewater using SDS. J Hazard Mater 2011; 185(2-3): 1304-10.

[http://dx.doi.org/10.1016/j.jhazmat.2010.10.046] [PMID: 21071142]

[3] Lesmana SO, Febriana N, Soetaredjo FE, et al. Studies on potential applications of biomass for the separation of heavy metals from water and wastewater. Biochem Eng J 2009; 44: 19-41. [http://dx.doi.org/10.1016/j.bej.2008.12.009]

[4] Kumar A, Bisht BS, Joshi VD, Dhewa T. Review on bioremediation of polluted environment: A management tool. Int J Environ Sci 2011; 1: 1079-93.

[5] Zhang XY, Lin FF, Wong MT, Feng XL, Wang K. Identification of soil heavy metal sources from anthropogenic activities and pollution assessment of Fuyang County, China. Environ Monit Assess 2009; 154(1-4): 439-49. [http://dx.doi.org/10.1007/s10661-008-0410-7] [PMID: 18597177]

[6] Seiler C, Berendonk TU. Heavy metal driven co-selection of antibiotic resistance in soil and water bodies impacted by agriculture and aquaculture. Front Microbiol 2012; 3: 399. 
[http://dx.doi.org/10.3389/fmicb.2012.00399] [PMID: 23248620]

[7] Bhatnagar A, Minocha AK, Sillanpaa DM. Bioch. Studying the removal of Co(II) from aqueous solution by using conducting polypyrrole. Eng J (NY) 2012; 48: 181-6.

[8] Manasi VR, Kumar ASK, Rajesh N. Preparation and evaluation of magnetic chitosan particles modified with ethylenediamine and Fe(III) for the removal of Cr(VI) from aqueous solutions. Chem Eng J 2014; 235: 1610-7.

[9] Kermani JN, Ghasemi MF, Khosravan A, et al. Bioremediation of cadmium by Bacillus safensis (JX126862), a marine bacterium isolated from mangrove sediments. J Environ Health Sci Eng 2010; 7: 279-86.

[10] Lin X, Mou R, Cao Z, et al. Characterization of cadmium-resistant bacteria and their potential for reducing accumulation of cadmium in rice grains. Sci Total Environ 2016; 569-570: 97-104. [http://dx.doi.org/10.1016/j.scitotenv.2016.06.121] [PMID: 27341110]

[11] Nogueira PFM, Nogueira MM, Lombardi AT. Influence of the microbial loop on trophodynamics and toxicity of cadmium complexed by cyanobacterium exudates. Environ Sci Process Impacts 2014; 16(5): 1029-34. [http://dx.doi.org/10.1039/c3em00550j] [PMID: 24619145]

[12] Krishna MP, Rinoy V, Arun VB, Mohamed HAA. Bioaccumulation of cadmium by Pseudomonas sp. isolated from metal polluted industrial region. Environ Res Eng Manag 2012; 61: 58-64.

[13] Bai RS, Abraham TE, Emila T. Studies on enhancement of Cr(VI) biosorption by chemically modified biomass of Rhizopus nigricans. Water Res 2002; 36(5): 1224-36

[http://dx.doi.org/10.1016/S0043-1354(01)00330-X] [PMID: 11902777]

[14] Fomina M, Gadd GM. Biosorption: current perspectives on concept, definition and application. Bioresour Technol 2014; 160 : 3-14. [http://dx.doi.org/10.1016/j.biortech.2013.12.102] [PMID: 24468322]

[15] Abbas SH, Ismail IM, Mostafa MT, Sulaymon AH. Biosorption of heavy metals: A review. J Chem Sci Tech 2014; 3: 74-102.

[16] Chojnacka K. Biosorption and bioaccumulation--The prospects for practical applications. Environ Int 2010; 36(3): $299-307$. [http://dx.doi.org/10.1016/j.envint.2009.12.001] [PMID: 20051290]

[17] Kaduková J, Vircíková E. Comparison of differences between copper bioaccumulation and biosorption. Environ Int 2005; $31(2)$ : 227-32. [http://dx.doi.org/10.1016/j.envint.2004.09.020] [PMID: 15661288]

[18] Pradel P, Corsini G, Tello M, Gonzalez A. Pantoea agglomerans an agent to remove residual copper from aquaculture activity. Adv Mat Res 2014; 945: 3479-82.

[19] Acioly LML, Júnior-Vilar C, Silveira AB. Isolation, identification, characterization and enzymatic profile of the new strain of Pantoea agglomerans. Int J Curr Microbiol Appl Sci 2017; 11: 4152-63.

[http://dx.doi.org/10.20546/ijcmas.2017.611.487]

[20] Sezonov G, Joseleau-Petit D, D’Ari R. Escherichia coli physiology in Luria-Bertani broth. J Bacteriol 2007; 189(23): 8746-9. [http://dx.doi.org/10.1128/JB.01368-07] [PMID: 17905994]

[21] Chang JS, Law R, Chang CC. Biosorption of lead, copper and cadmium by biomass of Pseudomonas aeruginosa PU21. Water Res 1997; 31: 1651-8.

[http://dx.doi.org/10.1016/S0043-1354(97)00008-0]

[22] Sanna G, Pilo M, Piu PC, et al. Determination of heavy metals in honey by anodic stripping voltammetry at microelectrodes. Anal Chim Acta 2000; 415: 165-73. [http://dx.doi.org/10.1016/S0003-2670(00)00864-3]

[23] Oliveira AG, Scarpa MV, Correa MA, et al. Microemulsões: estrutura e aplicações como sistema de liberação de fármacos. Quim Nova 2004; 27: 131-8. [http://dx.doi.org/10.1590/S0100-40422004000100023]

[24] Vijayaraghavan K, Yun YS. Competition of Reactive red 4, Reactive orange 16 and Basic blue 3 during biosorption of Reactive blue 4 by polysulfone-immobilized Corynebacterium glutamicum. J Hazard Mater 2008; 153(1-2): 478-86. [http://dx.doi.org/10.1016/j.jhazmat.2007.08.079] [PMID: 17913354]

[25] Chen P, Ting YP. Effect of heavy metal uptake on the electrokinetic properties of Saccharomyces cerevisiae. Biotechnol Lett 1995; 17: 107-12. [http://dx.doi.org/10.1007/BF00134205]

[26] Choi SB, Yun YS. Biosorption of cadmium by various types of dried sludge: An equilibrium study and investigation of mechanisms. J Hazard Mater 2006; 138(2): 378-83.

[http://dx.doi.org/10.1016/j.jhazmat.2006.05.059] [PMID: 16979815]

[27] Kang OL, Ramli N, Ahmad M. Cadmium (II) Biosorption onto Seaweed (Kappaphycus alvarezii and Eucheuma ddenticulatum) Waste Biomass: Equilibrium and Mechanism Studies -East. J Scient Research 2012; 11: 867-72.

[28] Mapolelo M, Torto N. Trace enrichment of metal ions in aquatic environments by Saccharomyces cerevisiae. Talanta 2004; 64(1): 39-47. [http://dx.doi.org/10.1016/j.talanta.2003.10.058] [PMID: 18969566]

[29] Stoll A, Duncan JR. Enhanced heavy metal removal from waste water by viable, glucose pretreated Saccharomyces cerevisiae cells. Biotechnol Lett 1996; 18: 1209-12. 
[http://dx.doi.org/10.1007/BF00128594]

[30] Sag Y, Kutsal T. Determination of the biosorption heats of heavy metal ions on Zoogloea ramigera and Rhizopus arrhizus . Biochem Eng J 2000; 6(2): 145-51.

[http://dx.doi.org/10.1016/S1369-703X(00)00083-8] [PMID: 10959085]

[31] Park D, Yun YS, Jo JH, Park JM. Mechanism of hexavalent chromium removal by dead fungal biomass of Aspergillus niger. Water Res 2005; 39(4): 533-40.

[http://dx.doi.org/10.1016/j.watres.2004.11.002] [PMID: 15707625]

[32] Bhakta JN, Ohnishi K, Munekage Y, Iwasaki K, Wei MQJ. Characterization of lactic acid bacteria-based probiotics as potential heavy metal sorbents. J Appl Microbiol 2012; 112(6): 1193-206. [http://dx.doi.org/10.1111/j.1365-2672.2012.05284.x] [PMID: 22404232]

[33] Michalak I, Chojnacka K, Witek-Krowiak A. State of the art for the biosorption process--a review. Appl Biochem Biotechnol 2013; 170(6): 1389-416.

[http://dx.doi.org/10.1007/s12010-013-0269-0] [PMID: 23666641]

[34] Hou Y, Cheng K, Li Z, et al. Biosorption of Cadmium and Manganese Using Free Cells of Klebsiella sp. Isolated from Waste Water. PLoS One 2015; 10(10): e0140962. [http://dx.doi.org/10.1371/journal.pone.0140962] [PMID: 26505890]

[35] Brady D, Glaum D, Duncan JR. Copper tolerance in Saccharomyces cerevisiae. Lett Appl Microbiol Biotechnol 1994; 18: 245-50. [http://dx.doi.org/10.1111/j.1472-765X.1994.tb00860.x]

[36] Kiff RJ, Little DR. Biosorption of heavy metals by immobilized fungal biomass.Immobilization of Ions by Biosorption. Chichester, England: Ellis Horwood Limited Publishers 1986

[37] Ozdemir G, Ceyhan N, Ozturk T, et al. Biosorption of chromium (VI), cadmium (II) and copper (II) by Pantoea sp. TEM18. Chem Eng J 2004; 102: 249-53. [http://dx.doi.org/10.1016/j.cej.2004.01.032]

[38] Chang JS, Law R, Chang CC. Biosorption of lead, copper and cadmium by biomass of Pseudomonas aeruginosa PU21. Water Res 1997; 31: $1651-8$. [http://dx.doi.org/10.1016/S0043-1354(97)00008-0]

[39] Ozdemir G, Ozturk T, Ceyhan N, Isler R, Cosar T. Heavy metal biosorption by biomass of Ochrobactrum anthropi producing exopolysaccharide in activated sludge. Bioresour Technol 2003; 90(1): 71-4. [http://dx.doi.org/10.1016/S0960-8524(03)00088-9] [PMID: 12835060]

[40] Kinoshita H, Ohtake F, Ariga Y, Kimura K. Comparison and characterization of biosorption by Weissella viridescens MYU 205 of periodic group 12 metal ions. Anim Sci J 2016; 87(2): 271-6. [http://dx.doi.org/10.1111/asj.12425] [PMID: 26223952]

[41] Kinoshita H, Sohma Y, Ohtake F, et al. Biosorption of heavy metals by lactic acid bacteria and identification of mercury binding protein. Res Microbiol 2013; 164(7): 701-9.

[http://dx.doi.org/10.1016/j.resmic.2013.04.004] [PMID: 23603782]

(C) 2018 Leandro Acioly et al.

This is an open access article distributed under the terms of the Creative Commons Attribution 4.0 International Public License (CC-BY 4.0), a copy of which is available at: (https://creativecommons.org/licenses/by/4.0/legalcode). This license permits unrestricted use, distribution, and reproduction in any medium, provided the original author and source are credited. 